\title{
RETT SYNDROME
}

\section{Clinical and epidemiological aspects in a Brazilian institution}

\author{
Cristina M. Pozzi ${ }^{1}$, Sergio Rosemberg ${ }^{1}$
}

\begin{abstract}
Rett syndrome (RS) is a neurodevelopmental disorder, preferentially found in females and specifically involving the functions on which intelligence and its expression depend - learning, hand use and speech leaving many others intact. Mutations have been identified at Xq28 on the MECP2 gene (methyl-CpG 2), which selectively silences the expression of other genes whose location is still unknown. This is a study on clinical, diagnostic and epidemiological aspects of RS in a Brazilian sample. It included 33 female patients with chronic encephalopathy without known etiology. RS was diagnosed in 24 patients (72.7\%): 17 (70.8\%) had classical RS; 5 (20.8\%), atypical RS and 2 (8.4\%), potential RS. In 9 girls clinical data and/or laboratory studies excluded diagnosis of RS. Among the atypical RS patients, 4 were form fruste and one, congenital form. Among the girls with other encephalopathies, cerebral malformation was the most frequent finding.
\end{abstract}

KEY WORDS: Rett syndrome, chronic encephalopathy, differential diagnosis.

\section{Delineação da síndrome de Rett, forma clássica e variantes: diagnóstico diferencial}

RESUMO - Síndrome de Rett (SR) é desordem do neurodesenvolvimento que afeta preferencialmente meninas e envolve especificamente funções cognitivas - aprendizado, habilidade manual e linguagem - deixando outras intactas. Foram identificadas mutações no gene MECP2 (Metil-CpG 2) localizado no Xq28, que silencia seletivamente a expressão de outros genes que aguardam identificação. Este estudo baseia-se em aspectos clínico-diagnósticos e epidemiológicos da SR numa casuística brasileira. Foram estudadas 33 crianças do sexo feminino portadoras de encefalopatia crônica sem evidência de etiologia para o quadro. Em 24 pacientes (72,7\%) fez-se o diagnóstico de SR: 17 (70,8\%) com SR clássico, 5 (20,8\%) com SR atípico e 2 (8,4\%) com SR potencial; em 9 pacientes o diagnóstico de SR foi excluído através de dados clínicos e / ou exames complementares. Entre os casos de SR atípico, quatro eram forma frustra e um, forma congênita. Entre os casos com outras encefalopatias, malformação cerebral foi o achado mais freqüente.

PALAVRAS-CHAVE: síndrome de Rett, encefalopatia crônica, diagnóstico diferencial.

Although Rett syndrome (RS) was first described by Andreas Rett in 1966', this disorder became internationally recognized only after the report of Hagberg et al. in $1983^{2}$. It is a neurodevelopmental disorder which affects almost exclusively girls and is associated with deceleration of head growth, typical stereotyped hand movements, severe mental deficiency, cortical and extrapyramidal dysfunction including gait disturbance and truncal ataxia as well as loss of purposeful use of the hands ${ }^{3,4}$. It is identified worldwide among all ethnic groups. The first case in the South Hemisphere was described by Rosemberg et al. in $1986^{5}$ and the first five Brazilian cases were reported in this Journal in $1987^{6}$. Prevalence is estimated between 1:10.000 and 1:15.000 girls ${ }^{7}$.
Until 1999, there was no known biochemical, morphological or genetic marker for RS and diagnosis was established on clinical criteria ${ }^{8}$. Recently, Amir, et al. have identified mutations on the gene MECP2, which is located on Xq28 and encodes methyl-CpG-binding protein 2 (MeCP2), in patients with RS, both in classic and non-classic forms ${ }^{9}$. Mutations have been found in about $80 \%$ of RS patients ${ }^{10}$. MeCP2 is an abundant chromosome-binding protein that acts as a global transcriptional repressor. It remains to be determined why mutation on M ECP2 leads to such as specific phenotype as seen in RS and how it produces this phenotype ${ }^{11}$. The clinical characteristics and differential diagnosis of RS vary according to the stage of the disease ${ }^{12}$. Classical RS

1MD, Neurology Division Department of Paediatrics, Santa Casa Medical School, Sao Paulo, SP Brazil.

Received 14 March 2003, received in final form 24 June 2003. Accepted 14 July 2003.

Dra. Cristina M Pozzi - Rua Joaquim Távora 1161/23 - 04015-002 São Paulo SP - Brasil. E-mail: cristinapozzi@ig.com.br 
fulfils the diagnostic criteria proposed by the Rett Syndrome Diagnostic Criteria Work Group and presents a clinical profile consistent with the one suggested by Hagberg and Witt-Engerström ${ }^{8,12}$.

With growing experience, RS patients who present a much wider and more heterogeneous phenotype than the originally described are considered as having atypical forms of the disorder ${ }^{13}$. A small number of cases (5-10\%) belong to an Early Onset Seizure Subgroup, which occurs in both classical and atypical RS. It constitutes a special subgroup until further elucidation ${ }^{13}$. The form fruste subgroup is characterized by surprisingly well-preserved, yet somewhat dyspraxic hand functioning, as well as absence of the classic RS stereotypies. Moreover, in the vast majority, the head circumference curves have remained within normal limits and it has not been possible to establish an early convincingly mental deterioration ${ }^{13}$. the late regression subgroup and the more controversial preserved speech subgroup represent fairly recent experience and appear to be of great importance in clinical RS research ${ }^{13,14}$. At the other end of the clinical RS panorama is a small variant group of severely damaged girls with a congenital onset RS. These girls may show floppiness and abnormal development from birth or their deterioration may occur so early and rapidly, that previous normal development is obscured on retrospective assessment. Nevertheless, long-term follow-up of such cases reveals a clinical profile and pattern consistent with $\mathrm{RS}^{4}$. The male form represents a phenocopy of the classical form in boys ${ }^{15,16}$.

A model for the clinical definition of atypical cases of RS has been elaborated by a Swedish-Norwegian collaborative study ${ }^{13}$. The experience from the Swedish series indicates that at least $25 \%$ of all clinical presentations are atypical and among these, the form fruste predominates, constituting $85 \%$ or more of atypical $\mathrm{RS}^{4}$.

Knowing that clusters of the characteristic diagnostic signs and symptoms sometimes do not develop before school age and that there is a growing number of young girls, usually between one to three years of age, who are suspected of having RS but without sufficient clinical evidence for a clearly established diagnosis, it has been suggested ${ }^{17}$ the use of a provisional classification with subgrouping into three diagnostic categories, which include classical RS, atypical RS and provisional or potential RS. The last subgroup comprises all girls with an unexplained developmental delay and/or loss of functional abilities, particularly acquired hand skills. These young girls would certainly benefit from being included into the
"Rett family" early: understanding their particular problems, these girls could now be incorporated into specific rehabilitation programs at an earlier stage ${ }^{17,18}$.

The present study has the purpose of performing a clinical analysis of a cohort of girls with chronic encephalopathy without a recognizable evident etiology, who were referred to our neuropediatric service, in order to 1) establish, within this Brazilian sample, the prevalence of RS, 2) determine the frequency of its different variants, 3) identify the etiology of the nonRS cases, and 4) discuss the limits of the current RS diagnostic criteria in view of the clinical and laboratory particularities found in some of our cases.

\section{METHOD}

Forty female patients, who were referred to the Neuropediatric Division of Santa Casa Medical School between January 1995 and January 1998, were studied. For inclusion, patients should present a chronic encephalopathy, characterized by global psychomotor developmental delay, without evident etiology, including absence of pre, peri or postnatal abnormalities.

Once fulfilled these criteria, all patients were submitted to an established protocol as follows: detailed anamnesis, complete physical and neurological examination and application of the diagnostic criteria for Classical and atypical RS as proposed by The Rett Syndrome Diagnostic Criteria Work Group ${ }^{8}$ and Hagberg and Skjeldal ${ }^{13}$. Laboratory studies performed in all cases included: EEG, computed tomography (CT) scan of the brain, ophthalmologic evaluation, cerebrospinal fluid (CSF) analysis, chromosomal analysis, screening tests for inborn errors of metabolism (STEM) and X-rays of the vertebral column. If indicated, other exams such as electroneuromyography or serologic tests were performed.

For the statistical analysis it was used the " $\mathrm{t}$ " test (Student).

\section{RESULTS}

Seven patients discontinued follow-up and were removed from the study. The remaining 33 patients were divided in two groups: group I: 24 cases (72,7\%) with RS, divided into: subgroup IA: 17 cases $(70,8 \%)$ with classical RS; subgroup IB: 5 cases $(20,8 \%)$ with atypical RS; and subgroup IC: 2 cases $(8,4 \%)$ with provisional or potential RS; group II: 9 cases $(27,3 \%)$ with encephalopathy other than RS.

Clinical data of all patients are presented in Table 1. Table 2 lists the current patient age, age at diagnosis and age at onset of the disease. The average current age, the age of onset and age of diagnosis are higher in atypical form when compared with classical form, with a statistic significance at $t_{20}=$ $2,10, t_{20}=-2,44, t_{20}=-2,34 ; p<0,05$; respectively. 


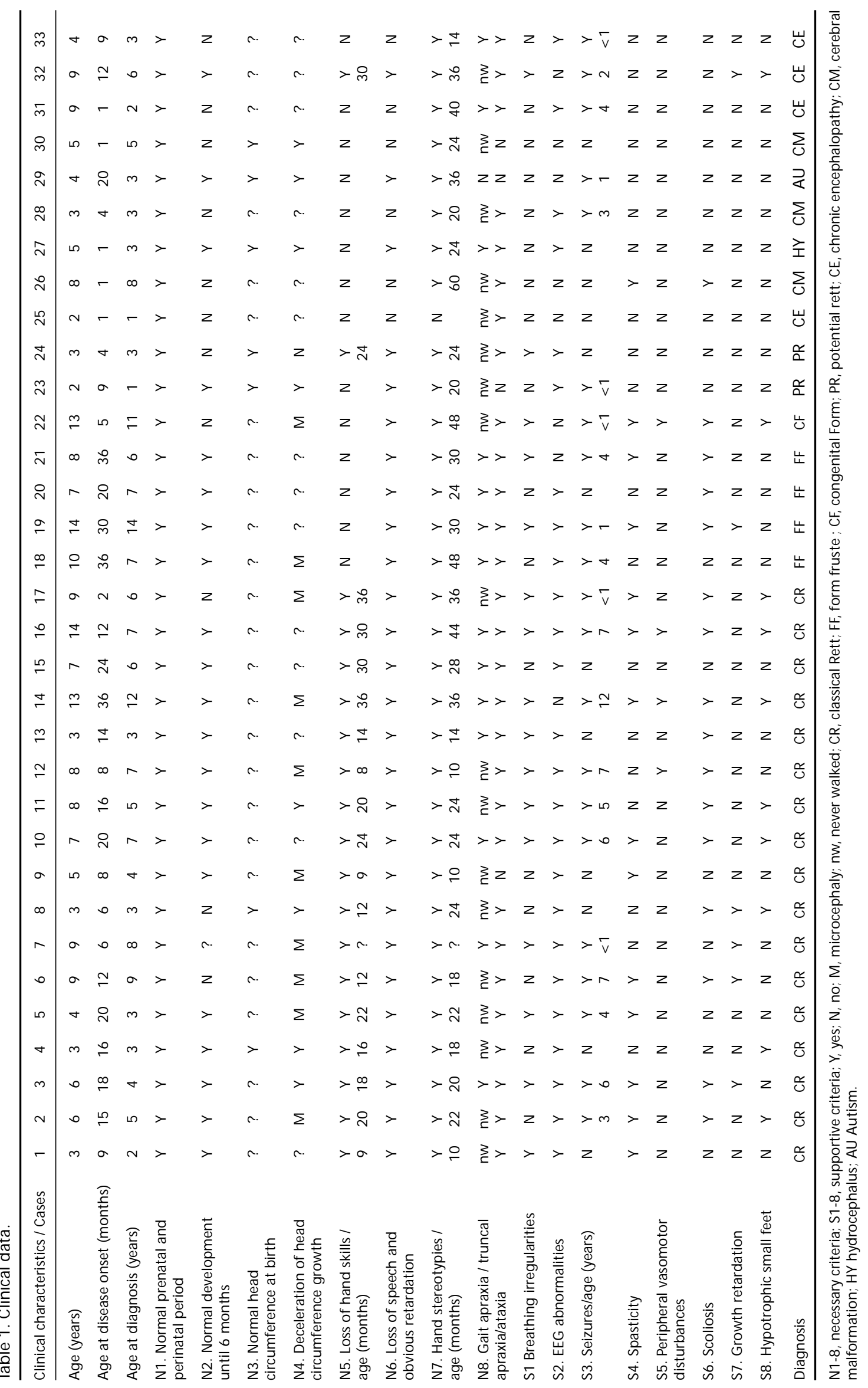


Table 2. Patient age, age at diagnosis and age at onset of the disease..

\begin{tabular}{lcccc}
\hline Characteristics / Groups & $\begin{array}{c}\text { Classical RS } \\
(\mathrm{n}=17)\end{array}$ & $\begin{array}{c}\text { Atypical RS } \\
(\mathrm{n}=5)\end{array}$ & $\begin{array}{c}\text { Potential RS } \\
(\mathrm{n}=2)\end{array}$ & $\begin{array}{c}\text { Non-RS Cases } \\
(\mathrm{n}=9)\end{array}$ \\
\hline Patient age (years) & $6,9 \pm 3,3$ & $10,4 \pm 3,0$ & $2,5 \pm 0,7$ & $5,4 \pm 2,6$ \\
Age at diagnosis (years) & $5,5 \pm 2,6$ & $9,0 \pm 3,4$ & $2,5 \pm 0,7$ & $3,7 \pm 2,1$ \\
Age at onset of the disease (months) & $14,2 \pm 8,1$ & $25,4 \pm 13,1$ & $6,5 \pm 3,5$ & $5,5 \pm 6,7$ \\
\hline
\end{tabular}

Comparison classical RS $X$ atypical RS: patient age $t_{20}=-2,10$ sign; age at diagnosis $t_{20}=-2,44$ sign; age at onset of the disease $t_{20}=-2,34$ sign

Table 3. Frequency of clinical data.

\begin{tabular}{|c|c|c|c|c|}
\hline $\begin{array}{l}\text { Clinical characteristics / } \\
\text { Groups }\end{array}$ & $\begin{array}{l}\text { Classical RS } \\
(n=17) n^{\circ}\end{array}$ & $\begin{array}{l}\text { Atypical RS } \\
(n=5) n^{\circ}\end{array}$ & $\begin{array}{l}\text { Potential RS } \\
(n=2) n^{\circ}\end{array}$ & $\begin{array}{l}\text { Non-RS cases } \\
\quad(n=9) n^{\circ}\end{array}$ \\
\hline Normal pre / perinatal period & 17 & 5 & 2 & 9 \\
\hline $\begin{array}{l}\text { Normal development until } \\
\text { age of } 6 \text { months }\end{array}$ & 13 & 4 & 1 & 3 \\
\hline Loss of hand skills & 17 & 0 & 1 & 1 \\
\hline Loss of speech & 17 & 5 & 2 & 3 \\
\hline Hand stereotypies & 17 & 5 & 2 & 8 \\
\hline Breathing irregularities & 11 & 3 & 1 & 2 \\
\hline EEG abnormalities & 16 & 3 & 2 & 4 \\
\hline Seizures & 11 & 4 & 1 & 5 \\
\hline Spasticity & 10 & 3 & 0 & 1 \\
\hline Peripheral vasomotor disturbances & 3 & 1 & 0 & 0 \\
\hline Scoliosis & 11 & 4 & 0 & 1 \\
\hline Growth retardation & 4 & 1 & 0 & 1 \\
\hline Hypotrophic small feet & 8 & 1 & 0 & 1 \\
\hline
\end{tabular}

Table 3 presents the frequency of clinical data among the different subgroups. Table 4 shows the clinical data of patients of subgroup IB according to the diagnostic model for atypical $\mathrm{RS}^{13}$.

Investigation through ophthalmoscopic examination, karyotype, CSF, and STEM was normal in all patients of group I except in case 17 who showed a persistently elevated protein level in CSF (values of 42,68 and $46 \mathrm{mg} / \mathrm{dl}$, with 3 and 22 months interval), a positive Pandy reaction and normal protein electrophoresis. Brain CT scan revealed frontal atrophy in two patients of this group (cases 1 and 6) and was normal in the others. EEG was normal in only 4 girls, the most frequent finding being diffuse slowing (10 girls).

All patients of group II showed normal karyotype, STIEM and CSF examination. Ophthalmoscopic exa- mination revealed a pale optic disk in patient 26 and chorioretinitis in patient 32. Brain CT was normal in three and revealed corpus callosum malformation in two patients, diffuse cortical atrophy in other two patients and periventricular leukomalacia and moderate ventricular dilatation were found in one patient each. The EEG was normal in five cases and diffuse slowing was observed in three.

\section{DISCUSSION}

The type of presentation, clinical characteristics and clinical course of the patients with classical RS are consistent with the diagnostic criteria proposed in 1988 by the "Rett Syndrome Diagnostic Criteria Workgroup" ${ }^{8}$. Muscular hypotonia during the first months of life and relative delay in the development 
Table 4. Application of diagnostic model for atypical RS in patients of subgroup IB.

\begin{tabular}{|c|c|c|c|c|c|}
\hline Clinical characteristics / Case number & 18 & 19 & 20 & 21 & 22 \\
\hline Age (years) & 10 & 14 & 7 & 8 & 13 \\
\hline Al.Loss of fine finger skill & + & + & + & + & - \\
\hline A2.Loss of acquired speech & + & + & + & + & - \\
\hline A3. Hand stereotypies & + & + & + & + & + \\
\hline A4.Deviant communicative ability & + & + & + & + & + \\
\hline A5.Deceleration of head circumference growth & M & $?$ & $?$ & $?$ & M \\
\hline A6.Clinical RS profile & + & + & $?$ & $?$ & + \\
\hline B1.Breathing irregularities & - & + & - & + & + \\
\hline B2. Bloating / marked air swallowing & - & - & - & - & + \\
\hline B3. Teeth grinding & - & + & + & - & + \\
\hline B4.Gait apraxia & + & + & + & + & - \\
\hline B5.Scoliosis / kyphosis & - & + & + & + & + \\
\hline B6.Neurologic lower limb abnormalities & - & - & - & - & + \\
\hline B7.Small cold feet with autonomic/trophic dysfunction & - & - & - & - & + \\
\hline B8.EEG abnormalities & + & + & + & - & - \\
\hline B9.Unprompted laughing/screaming spells & + & + & - & + & + \\
\hline B10.Impaired nociception & + & - & - & + & + \\
\hline B11."Eye pointing" & + & + & + & + & + \\
\hline
\end{tabular}

A, inclusion criteria; B, supportive criteria; +, present; -, absent; M, microcephaly.

were observed in three patients (cases 6, 8 and 17). Opitz points out the frequency of hypotonia before the first stage of the disease ${ }^{19}$. Neuromotor development in all other cases (except case 7 in which this data was not available) was normal until the $6^{\text {th }}$ month of life and average start of disease was at $14,2 \pm 8,1$ months of age, which is consistent with findings of Naidu et al. ${ }^{20}$. The frequency of supportive diagnostic criteria observed in group I are consistent with findings in the literature ${ }^{21,22}$. Among these, EEG abnormalities and seizures were the most frequent findings, followed by scoliosis and breathing irregularities. The correct evaluation of the deceleration of head circumference was difficult to access due to the absence of head circumference measurements at birth in most cases.

Among the cases of classical RS, case 17 deserves special mention. This nine-year old girl whose pre or perinatal history was uneventful presented seizures at two months of age, which were subsequently controlled. Her neurodevelopment was delayed. She picked up objects at 6 months of age, sat unsuppor- ted at 12 months and never talked. At 20 months of age, her condition worsened. It was observed a loss of interest in her surroundings, ready crying and irritability. At 3 years of age, typical stereotyped hand movements appeared with loss of use of her hands. Scoliosis, microcephaly, spasticity, truncal ataxia, apneic episodes and small feet with trophic alterations were observed. CSF examination revealed increased protein levels on three occasions at intervals of three and 22 months. This is an intriguing case in that this patient fulfils all criteria for classical RS. Until now, no other similar cases of RS have been described. This CSF alteration has not been included as exclusion criteria as well. Electrophoresis of CSF protein and electroneuromyography were normal. The cause of this protein elevation in CSF remains obscure. The incidence of atypical RS in this study was $20,8 \%$. Of these, $80 \%$ were form fruste (FF). This finding is consistent with the Swedish studies where $25 \%$ of clinical presentations are atypical and among those, FF predominated, representing 85\% of the cases ${ }^{4}$. 
The clinical course in FF is more protracted. In our experience, symptoms started later than in classical RS and consequently the diagnosis of the disease was postponed to a later age. Among the FF, only case 18 presented with microcephaly, the other three patients had normal head circumference. FF patients preserved certain hand skills such as the ability to feed themselves or scribble on paper. This was not observed in classical RS cases. All are ambulatory. Cases 20 and 21 have been considered FF despite minimum age for diagnosis being 10 years of age. They are on follow-up and fulfil all diagnostic criteria for atypical RS.

Case 22 is a 13-year-old patient without pre or perinatal history. She was hypotonic since the first months of life and presented important delay of motor development: she was ableto sit without support only at 7 years of age. She never walked and had a seizure at 2 months of age, which never recurred. She never used her hands. At 30 months of life, she held her hands in her mouth most of the time and at the age of 4 years, typical stereotyped hand movements appeared. At 8 years of age, she showed better axial stability and appeared to have better contact with her surroundings: she showed visual interaction and presented episodes of spontaneous unmotivated laughter. She had scoliosis and small feet with trophic and vasomotor disturbances. EEG was normal. This case seems to fit into the congenital form group and clinical course revealed little progress with rehabilitation.

Cases 23 and 24 have suspected RS but without sufficient clinical evidence to establish the diagnosis: they are two and three year old, respectively. The former presents certain hand functioning and the latter, absence of deceleration of head circumference growth. Considering the provisional classification suggested in $1994^{17}$, these girls were grouped as potential RS.

Cerebral malformation was the most frequent diagnosis in group II and infantile autism was diagnosed in only one case. In this group, two cases deserve special mention. Case 27 is a 5 year old girl whose phenotype is very similar to RS: there was no significant pre or perinatal history, it was noted hypotonia during the first few months of life although she was able to sit unsupported at the age of 9 months and could walk at 17 months. She babbled but could not talk and did not respond to any verbal command. At about two and a half years of age, she started showing irritability and self-aggression together with the typical stereotyped hand movements of RS. There was no deceleration of head circumference growth and she manifested certain hand skills although only gross grasping. EEG revealed diffuse slowing and brain TC scan, a communicating hydrocephalus. Had this patient 10 years of age, she would have been considered as having a form fruste of RS. However, by definition ${ }^{8}$, the CT findings exclude this girl from the RS family.

Patient 32 is a 9-year-old girl who completely fulfils the clinical criteria for RS: the pre and perinatal history was uneventful and the motor development was normal until 6 months of age. She has never walked nor uttered monosyllabic words. At 2 years of age she had seizures which were controlled. With 3 years of age it was noted typical stereotyped hand movements. She cannot use her hands, does not talk and deceleration of head circumference was documented. There was irregular breathing. Ophthalmologic examination revealed a chorioretinitis plaque in the right eye. She had positive IgG serology for toxoplasmosis and the possibility of ocular toxoplasmosis could not have been ruled out. This patient fulfils RS criteria but was excluded from group I by definition because of retinopathy and a probable acquired infectious disease (toxoplasmosis) ${ }^{8}$.

The latter two observations raise the question about the validity of some exclusion criteria for the diagnosis of $\mathrm{RS}^{8}$ such as retinopathy or acquired neurological disorders.

The discovery of mutations in the MECP2 gene allows the confirmation of clinical diagnosis and the development of genotype-phenotype correlations. It also allows a careful molecular examination of the patients that do not meet all diagnostic criteria for $\mathrm{RS}^{23}$. Mutations in the MECP2 gene was also found in encephalopatic males, in X-linked mental retardation and in patients with Angelman syndrome, showing that there is a broad variability in the clinical phenotype of M ECP2 mutations ${ }^{10,24}$. Detailed clinical studies of the patients together with the new molecular discoveries should provide insight into the pathogenesis of RS and a better understanding of the disease.

Acknowledgements - We are indebted to Elkis \& Furlanetto Laboratory of Clinical Analysis for having performed the karyotypes and screening tests for inborn errors of metabolism. 


\section{REFERENCES}

1 Rett A. Uber ein eigenartiges hirnatrophisches Syndrom bei Hyperammonamie in kindersalter. Wien Med Wochenschr 1966;116:723-736.

2. Hagberg B, Aicardi J, Dias K, Ramos O. A progressive syndrome of autism, dementia, ataxia and loss of purposeful hand usein girls: Rett's syndrome: report of 35 cases. Ann Neurol 1983;14:471-479.

3. Armstrong DD. Review of Rett syndrome. J Neuropathol Exp Neurol 1997;56:843-849.

4. Hagberg B. Rett syndrome: clinical peculiarities and biological mysteries. Acta Paediatr 1995;84:971-976.

5. Rosemberg S, AritaFN, Campos C. A Brazilian girl with Rett syndrome. Brain Dev 1986;8:554-556.

6. Rosemberg S, Arita FN, Campos C, et al. Síndrome de Rett: análise dos primeiros cinco casos diagnosticados no Brasil. Arq Neuropsiquiatr 1987;45:143-152.

7. Kozinetz $C A$, Skender $M L$, Macnaughton $N$, et al. Epidemiology of Rett syndrome: a population-based registry. Pediatrics 1993;91:445-450.

8. Diagnostic criteria for Rett syndrome. The Rett Syndrome Diagnostic Criteria Work Group. Ann Neurol 1988;23:425-428.

9. Amir RE, Van Den Veyver IB, Wan M, Tran CQ, Francke U, Zoghbi HY. Rett syndrome is caused by mutations in X-linked MECP2, encoding methyl-CpG-binding protein 2. Nat Genet 1999;23:185-188.

10. Webb T, Latif F. Rett syndrome and the MECP2 gene. J Med Genet 2001;38:217-223.

11. Shahbazian MD, Zoghbi HI. Molecular genetics of Rettsyndromeand dinical spectrum of MECP2 mutations. Curr Opin Neurol 2001;14:171-176.
12. Hagberg B, Witt-Engerström I. Rett syndrome: a suggested staging system for describing impairment profile with increasing age towards adolescence. AmJ Med Genet 1986;1(Suppl):47-59.

13. Hagberg BA, Skjeldal OH. Rett variants: a suggested model for inclusion criteria. Pediatr Neurol 1994;11:5-11.

14. Zapella M. The Rett girls with preserved speech. Brain Dev 1992;14:98-101

15. Christen HJ, Hanefeld F. Male Rett variant. Neuropediatrics 1995;26:81-82.

16. Topçu M, Topaloglu H, Renda $Y$, Berker M, Turanli G. The Rett syndrome in males [Letter]. Brain Dev 1991;13:62.

17. Hanefeld F, Hagberg B, Percy A. Molecular and neurobiology aspects of Rett syndrome. Neuropediatrics 1995;26:60-61.

18. Hagberg B. Clinical delineation of Rett syndrome variants. Neuropediatrics 1995;26:62.

19. Opitz JM. Rett syndrome: some comments on terminology and diagnosis. AmJ Med Genet 1986;1(Suppl):27-37,

20. Naidu S, Hyman S, Harris EL Narayanan V, Johns D, Castora F. Rett syndrome studies of natural history and search for a genetic marker. Neuropediatrics 1995;26:63-66.

21. Naidu S, Murphy M, Moser HW, RettA. Rett syndrome: natural history in 70 cases. AmJ Med Genet 1986;1(Suppl):61-72.

22. Philippart M. Clinical recognition of Rett syndrome. Am J Med Genet 1986;1(Suppl):111-118.

23. Percy AK. Rett syndrome: clinical correlates of the newly discovered gene. Brain Dev 2001;23 (Suppl 1):202-5.

24. Couvert $P$, Bienvenu $T$, A quaviva $C$ et al. MECP 2 is highly mutated in X-linked mental retardation. Hum Mol Genet 2001;10:941-946. 